\title{
ALPK2 Gene
}

National Cancer Institute

\section{Source}

National Cancer Institute. ALPK2 Gene. NCI Thesaurus. Code C115982.

This gene is involved in protein phosphorylation. 